\title{
DANCE TEACHING IN NATIONAL PROGRAMS IN BRAZIL AND PORTUGAL
}

\author{
ENSINO DE DANÇA EM PROGRAMAS NACIONAIS NO BRASIL E PORTUGAL
}

\author{
ENSEÑANZA DE DANZA EN PROGRAMAS NACIONALES EN BRASIL Y \\ PORTUGAL
}

Maria João Alves*, Adriana de Faria Gehres**, Elisabete Alexandra Pinheiro Monteiro*, Lívia Tenório Brasileiro**

\begin{abstract}
Keywords:
Dance.

Physical education.

Art.

Curriculum.

Abstract: This study examines the fundamental principles of dance teaching (GEHRES, 2008) in national programs in Brazil and Portugal. In Brazil we selected the Curricular Orientations and Parameters in Physical Education and Art; in Portugal we focused on the Programs of Physical Education and the Alternative Proposal for Dance Education for the second part of Primary Education. Taking the aim of the investigation into consideration, we chose to conduct analytical philosophical research which, according to Thomas and Nelson (2002), aims at critical investigation, the study of facts and the synthesis of variables to analyze the existing material under a viable theoretical model. The investigation of the guideline documents of the two countries showed predominance of subjective proposals in both nations. However, Portugal and Brazil diverge in terms of their focuses; Portugal has an objective approach while Brazil focuses on interactionism.
\end{abstract}

Palavras-chave: Dança. Educação Física. Arte. Currículo.

Palabras clave: Baile. Educación física. Arte. Curriculum.
Resumo: Este estudo teve como objetivo analisar os fundamentos do ensino da dança (GEHRES, 2008) nos programas nacionais do Brasil e de Portugal. No Brasil, selecionamos os Parâmetros e Orientações Curriculares em Educação Física e em Arte; em Portugal, os Programas de Educação Física e a Proposta alternativa para o ensino da dança no ensino fundamental II. Levando em conta o objetivo da pesquisa, optamos por realizar uma investigação filosófica do tipo analítica que, como nos diz Thomas e Nelson (2002), visa à investigação crítica, ao estudo dos fatos e à síntese das variáveis, procurando analisar o material existente a partir um modelo teórico viável. A investigação dos documentos orientadores dos dois países revelou a predominância em ambos os países de propostas subjetivistas. Contudo, foi observado que Portugal e Brasil divergiam no privilégio ao objetivismo em Portugal e ao interacionismo no Brasil.

Resumen: Este estudio tuvo como objetivo analizar los fundamentos de la enseñanza de danza (GEHRES, 2008) en los programas nacionales de Brasil y Portugal. En Brasil, seleccionamos los Parámetros y Directrices Curriculares en Educación Física y Arte; en Portugal, los Programas de Educación Física y la propuesta alternativa para la enseñanza de danza en la educación primaria II. Considerando el objetivo del estudio, optamos por realizar una investigación filosófica de tipo analítico que, como nos dice Thomas y Nelson (2002), tiene como objetivo la investigación crítica, el estudio de los hechos y la síntesis de las variables, tratando de analizar el material existente a partir de un modelo teórico viable. La investigación de los documentos de orientación de los dos países reveló el predominio, en ambos países, de propuestas subjetivistas. Sin embargo, se observó que Portugal y Brasil difieren en que en Portugal se privilegia el objetivismo y en Brasil el interaccionismo.
*Universidade de Lisboa. Lisboa, Portugal.

E-mail: mjalves@fmh.ulisboa.pt

**Universidade de Pernambuco. Recife, PE, Brasil.

E-mail: agehres@yahoo.com

Recebido em: 18-05-2016 Aprovado em: 05-04-2017

(c) (1) (8) Licence 


\section{INTRODUCTION}

Brazil and Portugal share social-political-cultural relations which date back to a distant past and last until the present time. In the current world, these relations, contacts and contamination are intensified in a global scale. In this context, in which there are global and local communication at large, we carried out an analytical documentation study in order to compare the epistemic-methodological fundamental principles of the curricular documentation guidelines for dance education in the schooling process in these two countries, or, as Brasileiro (2009, 2001) states, in dealing with knowledge of Dance in schools.

In this context, in both countries, we identified a polarity between dance education as content or modality of the curricular component of Physical Education and as one of the artistic languages to be taught in the curricular component of Art in Brazil and Artistic Education in Portugal.

Another aspect to point out is what we understand as guideline documents for dance education. Vieira (2007) presents a descriptive model of curriculum, which informs us that the curriculum is made up of three large levels of action which define its forms of being. The first describes the curriculum as text, ideal and formal, con-substantiated in legal guideline documents more and/or less general which range from national programs to school manuals, for example. The second level presents itself as an operational curriculum or as teachers implement the curriculum in their pedagogical interventions. The third level of the model makes reference to the curriculum as experienced by the students in all school moments. According to the author, it is in the congruence of these three levels that the curriculum is realized as an actual fact.

In this study, we emphasize the description of the first curricular level, the curriculum as text, represented by the legal documents which materialize policies and government intentions for Dance in Education.

According to Gehres (2008), the proposals for dance education are organized, in the epistemic-philosophical point of view, as two large categories: 1) those which the reason/ experience dichotomies; 2) those which try to overcome these dichotomies in the construction of integration proposals of the dichotomous aspects (and, in this sense, still modern), but incorporating and valuing presupposed concepts related to discourses which are generically recognized as post-modern or critical of modernity in Dance, or as more recently understood, post-critical: the denouncement of the great meta-narratives and of the micro-forms of power, the appreciation of cultural multiculturalism and Dance as language.

In the first category, the rationalist-objective proposals were identified which give importance to reason and the object or knowledge in the teaching-learning process and the perspectives which, on the other hand, concentrate the experience of the senses (KELLY, 1986) and the subject of knowledge in the teaching-learning process.

In regards to the rational-objective proposals, two models were identified: traditional and scientific. The traditional model for dance education is based in the existence of an object to be taught (the uninterested work of art of the enlightened modernity) by a teacher who transmits knowledge. In dance, this perspective is identified in teaching, for example, classical, modern and social dances in the formal context of teaching. The scientific model (ADSHEAD, 1988), on its turn, is presented under two formats: "dance as movement", in which importance is 
given to measurable and identifiable movement in its anatomic, physiologic, bio-mechanic and psychological aspects as an object to be transmitted and assessed; and "dance as art", in which importance is given to dance as an object of "[...] aesthetic and artistic appreciation of a rational and objective character" (GEHRES, 2008, p. 22).

The empiricist-subjective proposals for dance were forged within modern dance from the beginning of the $20^{\text {th }}$ century, above all through the work of Isadora Duncan in the United States and Rudolf Laban, initially in Germany and later in England. However, it will be through the systematization proposed by Rudolf Laban that we see a systematization of dance which will be known as modern dance education, dance education, creative dance, amongst others (MARQUES, 2003). These proposals are based in the presumed idea that all people are capable of dancing from the process of manipulation of movements. In this case, dance becomes an expressive project to be developed by the subject of dancing.

In the second category, from the proposals that aim at overcoming the reason/ experience, object/subject dichotomy through the interactivity which incorporates aspects of the critical discourses of the instituted modernity, Gehres (2008) identified the work of dancers, choreographers, researchers who centered their proposals in the construction, discussion and questioning of the subject who dances in a real context, contemporary society with its conflicts and tensions. Preston Dunlop (1988), with a existential-artistic-social connotation. Shapiro (1998), Taylor (1994), and Stinson (1995, 1998a, 1998b, 2005) in their denouncement of the idealism which is present in modern dance education and the micro-forms of power in dance education, on gender, for example; and Marques $(1999,2003)$ in their criticism to the great universal meta-narratives for dance education (classical dance and modern dance education) and in giving importance to cultural diversity. More recently, we can also identify in Marques (2010), the deepening of a perspective of dance as language. All of these proposals point to a search for overcoming modern dichotomies through approaching the contemporary post-critical perspectives.

This study aims at analyzing the fundamental principles of dance education (GEHRES, 2008) in national programs in Brazil and Portugal. Thus, we organized our investigation with the objective of examining how these presumed epistemic-philosophical (rationalist-objectivist, empiricist-objectivist or interactionist) ideas reveal themselves as epistemic-methodological fundamentals of the curricular proposals for dance education in the countries we signaled.

\section{METHODOLOGY}

To analyze curricular proposals from two different countries required, at first, to organize a team with members from both countries, two members were from Portugal and two from Brazil. They had different backgrounds, dance and physical education, but to compose the team we used the criteria of having a common base, the investigation on dance education in the schooling process. All members participated during the whole process of collecting and analyzing data.

Taking into consideration the objective of the investigation, we chose to carry out an analytical philosophical research which, as we are told by Thomas and Nelson (2002), aims at the critical investigation, the study of the facts and the synthesis of the variables at analyzing the existing material from a viable theoretical model. 


\subsection{Definition of the sample}

The selection of samples was established from two criteria: relevance of the document for dance education; and time the document remained as guideline for dance education. In both countries, we know that the documents were created in approximate periods of time, which, in many ways, represent proposals from different governments, with different creation processes, but answers to a demand from western countries of revision of curricular guidelines, which great part of European and Latin American (GENTILI; SILVA, 1996; VIEIRA, 2007).

Based on the criteria that has been described, we selected the documents which had greatest expression in these countries, since they had the participation of specialists in their making, they were largely promoted within the educational networks and are known to be materials used by teachers in the organization of their teaching actions, despite having received intense criticism by the academic community, from the way they were produced to the manner they were disseminated (CBCE, 1997; VIEIRA, 2007).

In Brazil, the process of construction of curricular documents from the 1990's began with the publication of National Curricular Parameters (PCNs) of Primary School from $1^{\text {st }}$ to $4^{\text {th }}$ grade, in 1997. This document was published in 10 volumes, the $6^{\text {th }}$ of which was devoted to Physical Education. The same took place with the PCNs of $5^{\text {th }}$ to $8^{\text {th }}$ grades which was published in 1998 , with 10 volumes being the $7^{\text {th }}$ dedicated to Art and the $8^{\text {th }}$ to Physical Education. These documents had, and still have, great circulation in the Brazilian cities and towns and they were the trigger for many states and towns to elaborate their own curricular proposals.

The version of the PCNs for secondary school was published in 2000, however, according to an assessment of the Ministry of Education, it is recognized that this document was not accepted by the education network and asks for a new process for a new national discussion on Secondary Education, which lead to the release of the National Curricular Orientations (OCNs), for Secondary Education in 2006. This document is divided into three volumes, which are: volume 1 - Languages, codes and their technologies, which encompass Physical Education and Art; volume 2 - Natural Sciences, Mathematics and their technologies; and volume 3 - Human Sciences and their technologies.

In this process, it was also constructed the National Curricular Referential for Children Education in 1998, however, it has no volume dedicated to specific areas of knowledge.

Following this, other curricular documents were produced aiming at guiding the national curricular organization'.

In Portugal, after the passing of the Bill of Basis for the Educational System in 1986, and the decree that established the areas of study throughout the three cycles of fundamental and secondary education in 1986, curricular programs for all subjects were organized by specialists (VIEIRA, 2007). For the first cycle, program in the area of expression and physical-motor education were organized, as well as for the other areas of expression (music, drama and art) and also Portuguese Language, Mathematics and Environmental Studies. For the second and third cycles, programs for the specific subjects were created. Thus, Physical Education developed programs in all education cycles, including secondary education. However, in the fields of Arts, only programs in the area of musical and visual arts education. After ten years

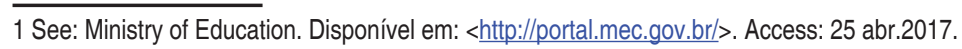


of its assessment and execution with teachers, these programs were reviewed and extended, becoming reference document for all fields (PORTUGAL, 1998, 2001a, 2001b, 2001c, 2004). As an isolated initiative, it was asked by Madalena Victorino to organize for the third cycle of education an experimental document in the field of dance, which could be developed as optional or extracurricular activity² (PORTUGAL, [2004]).

More recently, the Ministry of Education and Culture of Portugal proclaimed curricular goals for the different fields of education, but there is still no reference to the fields within this study.

Facing this scenario, for this research, we decided to analyze the documents presented in Figure 1

Figure 1 - Documents which were analyzed from Brazil and Portugal

\begin{tabular}{|c|c|c|c|c|}
\hline Country & Year & $\begin{array}{l}\text { Curricular } \\
\text { Component }\end{array}$ & Educational Cycle & Title \\
\hline Brazil & 2006 & $\begin{array}{l}\text { Physical Education } \\
\text { and Art Education }\end{array}$ & Secondary Education & Orientações Curriculares \\
\hline Brazil & 1998 & Art Education & $\begin{array}{l}\text { Primary Education - } \\
\text { 5th to 8th grades }\end{array}$ & Parâmetros Curriculares Nacionais \\
\hline Brazil & 1998 & Physical Education & $\begin{array}{l}\text { Primary Education - } \\
5 \text { th to 8th grades }\end{array}$ & Parâmetros Curriculares Nacionais \\
\hline Brazil & 1997 & Art Education & $\begin{array}{l}\text { Primary Education - } \\
1^{\text {st }} \text { to } 4^{\text {th }} \text { grades }\end{array}$ & Parâmetros Curriculares Nacionais \\
\hline Brazil & 1997 & Physical Education & $\begin{array}{l}\text { Primary Education - } \\
1^{\text {st }} \text { to } 4^{\text {th }} \text { grades }\end{array}$ & Parâmetros Curriculares Nacionais \\
\hline Portugal & 2001 & Physical Education & $\begin{array}{l}\text { Basic Education - } 3^{\text {rd }} \\
\text { cycle }\end{array}$ & $\begin{array}{c}\text { Programa de Educação Física } \\
\text { (readjustment) }\end{array}$ \\
\hline Portugal & 2001 & Physical Education & $\begin{array}{l}\text { Secondary Education } \\
-10^{\circ}, 11^{\circ}, 12^{\circ}\end{array}$ & Programa de Educação Física \\
\hline Portugal & 1998 & Physical Education & $\begin{array}{c}\text { Basic Education - } 2^{\text {nd }} \\
\text { cycle }\end{array}$ & Programa de Educação Física \\
\hline Portugal & $1998 / 2004$ & Physical Education & $\begin{array}{l}\text { Basic Education - } 1^{\text {st }} \\
\text { cycle }\end{array}$ & $\begin{array}{c}\text { Programa de Expressão e } \\
\text { Educação Físico Motora }\end{array}$ \\
\hline Portugal & {$[2004]^{3}$} & Art Education & $\begin{array}{l}\text { Basic Education - } 3^{\text {rd }} \\
\text { cycle }\end{array}$ & $\begin{array}{l}\text { Dança: Orientações Curriculares } \\
\text { (experimental document) }\end{array}$ \\
\hline
\end{tabular}

Source: survey data

\subsection{Data analysis procedure}

In order to establish the examination of the documents, we create descriptive categories (BARDIN, 2011), based on the theoretical construction which was previously defined by Gehres (2008).

2 This document came about as a request to Madalena Victorino to write the guidelines for dance education for the $1^{\text {st }}, 2^{\text {nd }}$ and $3^{\text {rd }}$ school cycles due to the fact that she had taught at High School of Dance. She started the course of Dance Education Methodologies, which later was called Dance Pedagogy and she had a teaching degree in Dance Pedagogy from the Laban Centre for Movement and Dance/Goldsmith's College from London University. This proposal had an experimental character but did not get to disseminated amongst teachers.

3 Although it is known that the document does not present data, it is known that it was made at the beginning of the 2000's. The references to the document indicate so. 
Figure 2 - Description of the type of indicators adopted by analyzed descriptive category

\begin{tabular}{|c|c|c|c|}
\hline Category & $\begin{array}{l}\text { Rationalist - objective } \\
\text { Indicators }\end{array}$ & $\begin{array}{l}\text { Empiricist } \\
\text { - subjective } \\
\text { Indicators }\end{array}$ & Interactionist Indicators \\
\hline Objectives & $\begin{array}{l}\text { Appreciation/ } \\
\text { Production }\end{array}$ & Creation & $\begin{array}{l}\text { Production, Creation, Appreciation } \\
\text { mediated by contextualization in the } \\
\text { cultural, social and critic meaning. }\end{array}$ \\
\hline Competences & $\begin{array}{l}\text { Knowledge of public artistic } \\
\text { conventions }\end{array}$ & $\begin{array}{l}\text { Creativity, Imagination } \\
\text { and individuality }\end{array}$ & $\begin{array}{c}\text { Knowledge of public artistic } \\
\text { conventions, creativity, imagination, } \\
\text { individuality mediated by cultural } \\
\text { diversity. }\end{array}$ \\
\hline Content & $\begin{array}{l}\text { Specific forms of dance } \\
\text { (techniques) }\end{array}$ & Principles of dance & $\begin{array}{l}\text { Physical techniques for body } \\
\text { awareness, selection of physical } \\
\text { techniques mediated by context, art } \\
\text { in contemporary times. }\end{array}$ \\
\hline Methodologies & $\begin{array}{c}\text { Closed, emphasis on } \\
\text { product and the acquisition } \\
\text { of abilities }\end{array}$ & $\begin{array}{l}\text { Open, emphasis on } \\
\text { process and feelings }\end{array}$ & $\begin{array}{l}\text { Combination of open and closed } \\
\text { methodologies. }\end{array}$ \\
\hline $\begin{array}{c}\text { Form of } \\
\text { Assessment }\end{array}$ & $\begin{array}{l}\text { Objective and on } \\
\text { performance of physical } \\
\text { abilities and of appreciation }\end{array}$ & $\begin{array}{l}\text { Subjective and on } \\
\text { creation }\end{array}$ & $\begin{array}{l}\text { Objective and subjective, measured } \\
\text { according to contextualization. }\end{array}$ \\
\hline
\end{tabular}

Source: survey data

As shown in figure 2 the analysis of content process of the documents was carried out in three moments: preview review of all documents; exploration of the material; and inference and interpretation (BARDIN, 2011). For the identification of the indicators in each one of the categories, we created a scale of representation value according to the presence or absence of indicators (objective, subjective, interactionist) in four levels: absent (-), brief reference $(+)$, moderate reference $(++)$, marked reference $(+++)$.

Researchers quotation were achieved in two moments. First, two members, one from each country, made a quotation of all the documents separately and then all members together had discussed their evaluations and took decisions about the final quotation.

\section{RESULTS AND DISCUSSION}

Results and discussion are presented simultaneously in two moments: 1) the identification analysis of the indicators in each of the categories for the documents for each country (TABLE 3); and a global analysis of the curricular proposals by country and by field (Art and Physical Education).

Table 3 reveals the relationship between several types of indicators in most of the guideline documents, with references which range from absent to marked.

Marked references were noticed, predominantly, for objective indicators in the Portuguese and Brazilian Physical Education documents and for interactionist indicators only in the Brazilian documents, but mainly in Art. Besides, marked and moderate references were quoted for objective and subjective indicators in all descriptive categories in both countries.

Such predominance can be seen in these extracts from the documents below: 
In rhythmic and expressive activities, it is possible to combine the rhythm and coordinated movements to each other. The cultural manifestations of the community itself or those shown by the media can be analyzed from the standpoint of some concepts of the quality of the movement such as, rhythm, speed, intensity and flow; they can be learned and also recreated (BRASIL, 1997b, p. 53) [authors translation].

In that Brazilian Physical Education for $1^{\text {st }}$ to $4^{\text {th }}$ grades documents, combination of rhythm and movements and the analysis of cultural manifestations that could be learnt or recreated are references of objective indicators in aims and content, as they are based in the re-production of movements and appreciation. In this case, it is an analysis of dance fundamentals of dance forms, which points out a rationalist perspective of dance education (GEHRES, 2008).

This is even more evident, when we analyze Portuguese Physical Education documents, for third cycle of fundamental and secondary education, which is widely descriptive for all body practices.

4.3 - Dance, MERENGUE, in the situation of Line Dance with definite space organization, and in the situation of dance in pairs, starting in the first measure and making it coincide with each step at one beat, making sequences of steps that match:

- steps on the spot and moving forward and backwards; - crossed steps front and back; - forward and backward steps with the same support, alternating with shifting weight to another support in place; - turning left and right (PORTUGAL, 2001a, p. 159) [authors translation].

Table 3 - Analysis of content of the type of indicators by curricular document, from Brazil and Portugal.

\begin{tabular}{|c|c|c|c|c|c|c|c|c|c|c|c|c|c|c|c|}
\hline \multirow{2}{*}{ Documents } & \multicolumn{3}{|c|}{ Objetives } & \multicolumn{3}{|c|}{ Competences } & \multicolumn{3}{|c|}{ Content } & \multicolumn{3}{|c|}{ Methodologies } & \multicolumn{3}{|c|}{$\begin{array}{l}\text { Forms of } \\
\text { assessment }\end{array}$} \\
\hline & 형 & 号 & $\dot{E}$ & 형 & 疍 & $\dot{I}$ & $\dot{3}$ & 今 & $\dot{E}$ & 흥 & 章 & $\ddot{E}$ & $\dot{3}$ & 音 & ث் \\
\hline $\begin{array}{l}\text { Brasil, 2006, Ensino da Arte, } \\
\text { Médio, Orientações Curriculares. }\end{array}$ & + & + & +++ & + & + & +++ & + & ++ & + & + & ++ & + & + & ++ & + \\
\hline $\begin{array}{l}\text { Brasil, 1998, Ensino da Arte, } \\
\text { Fundamental, } 5^{\mathrm{a}} \text { a } 8^{\mathrm{a}} \text {, Parâmetros. }\end{array}$ & ++ & ++ & ++ & +++ & ++ & ++ & ++ & + & +++ & + & ++ & +++ & + & +t & +++ \\
\hline $\begin{array}{l}\text { Brasil, 1997, Ensino da Arte, } \\
\text { Fundamental, } 1^{1 \mathfrak{a}} \text { a } 4^{\mathrm{a}} \text {, Parâmetros. }\end{array}$ & + & ++ & - & ++ & ++ & - & + & ++ & - & + & +++ & + & + & +t+ & + \\
\hline $\begin{array}{l}\text { Brasil, 2006, Educação Física, } \\
\text { Médio, Orientações Curriculares. }\end{array}$ & + & ++ & +++ & + & +++ & +++ & ++ & +++ & - & - & ++ & + & + & +++ & + \\
\hline $\begin{array}{l}\text { Brasil, 1998, Educação Física, } \\
\text { Fundamental, } 5^{\text {a }} \text { a 8 }{ }^{\mathrm{a}} \text {, Parâmetros. }\end{array}$ & +++ & ++ & - & +++ & ++ & - & +++ & ++ & - & ++ & ++ & - & ++ & ++ & + \\
\hline $\begin{array}{l}\text { Brasil, 1997, Educação Física, } \\
\text { Fundamental, 1ª a 4ª , Parâmetros. }\end{array}$ & ++ & ++ & - & + & + & - & +++ & + & - & ++ & + & - & ++ & ++ & + \\
\hline $\begin{array}{l}\text { Portugal, [2004]. Educação } \\
\text { Artística, Fundamental, } 3^{\circ} \text { ciclo, } \\
\text { Doc. Exp. }\end{array}$ & ++ & ++ & + & ++ & ++ & - & + & +++ & + & + & ++ & + & ++ & ++ & + \\
\hline $\begin{array}{l}\text { Portugal, 2001, Educação Física, } \\
\text { Secundário, Programa. }\end{array}$ & +++ & ++ & - & +++ & ++ & - & +++ & ++ & - & +++ & ++ & + & +++ & ++ & + \\
\hline $\begin{array}{c}\text { Portugal, 2001, Educação } \\
\text { Física, Básico, } 3^{\circ} \text { ciclo, Programa } \\
\text { reajustado. }\end{array}$ & t++ & +t & - & +++ & ++ & - & +++ & ++ & - & +++ & ++ & + & +++ & ++ & + \\
\hline $\begin{array}{l}\text { Portugal, 1998, Educação Física, } \\
\text { Básico, } 2^{\circ} \text { ciclo, Programa. }\end{array}$ & + & ++ & - & - & + & - & - & ++ & - & ++ & ++ & - & ++ & + & - \\
\hline $\begin{array}{l}\text { Portugal, 1998/2004, Educação } \\
\text { Física, Básico, 1ํ ciclo, Programa. }\end{array}$ & + & ++ & - & - & + & - & - & ++ & - & ++ & ++ & - & ++ & + & - \\
\hline
\end{tabular}

Key: (-) absent, (+) brief reference, $(++)$ moderate reference, $(+++)$ marked reference. 
Observing the text above, it is clear the presence of objective indicators for all descriptive categories. Reproduction of dance forms (social dance - merengue), taught through closed methodology with emphasis on product and the acquisition of abilities (spatial organization, rhythm, movement forms) which will also be evaluated by the observation of execution of physical abilities.

In contrast, interactionist indicators observed in the Brazilian documents are identified in these extracts below:

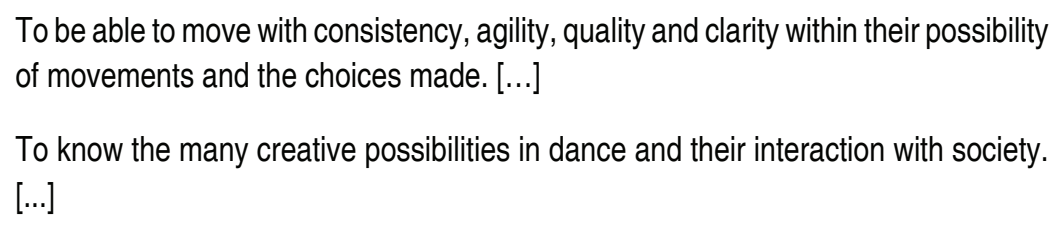

To be able to move with consistency, agility, quality and clarity within their possibility of movements and the choices made. [...]

To know the many creative possibilities in dance and their interaction with society. $[\cdots]$

To know the main historical trends of dance and the popular cultural manifestations and their influence in personal creative processes.

To be able to express with easy, clarity and discernment their ideas and opinions concerning the dances they create and watch (BRASIL, 1998a, p. 77-78) [authors translation].

Differently from objective indicators, this text about evaluation criteria, in the Brazilian Art document for $5^{\text {th }}$ to $8^{\text {th }}$ grades, reveals learning objectives and content which point out to interactionist indicators, when they present actions (move, know, express) about their own movements and manifestations of popular cultural, constantly related to an active participation of the person, through creation, execution, appreciation in the sense of personal and social criticism. Even though the forms of assessment are not outlined, we can infer that these could be objective and subjective, under a contextualized background.

In another extract, but in the Physical Education document for Secondary Education, we can also endorse the social active role aimed for the students in the learning process. Practical corporal experiences, awareness of body social role, control over rights, community movements practices, creation of own physical practices and political intervention applied to all body practices, materialize an interactionist approach, which directs to an "embodied" citizen (GREINER, 2008; DOMENECI, 2010).

\footnotetext{
Cultural accumulation in regards to creating opportunities for practical corporal experience; effective participation in the world of work in regards to the awareness of the role of the body in the world of production, related to the control over one's own effort and the right to rest and leisure; personal initiative in community movements related to physical community practices; personal initiative to create, plan or seek for orientation for one's own physical practices; political intervention on public sport, leisure and community organization initiatives in the manifestations, and cultural productions (BRASIL, 2006, p. 225).
}

It is also highlighted that contents are socially constructed and provoke different cultural themes to be discussed with the students in the school.

The contents Gymnastics, Sport, Games, Martial Arts and Dance as knowledge which was constructed by the human kind can be the stage of approaches of many different themes: gender, bodily practices in public areas, amongst others [...] Dance, however, also possesses historical, cultural and ethnic connections, as well as gender connections to be discussed at school (BRASIL, 2006, p. 229). [authors translation]. 
However, objective and subjective indicators were found in the documents of both countries, in all categories. As we had already analyzed some objective indicators for objective, competence, content, methodology and forms of assessment, the extracts below will show some subjective indicators for descriptive categories.

With regard to the category of objectives, one can observe in the document of the area of Art, for primary schools in Brazil, the indicators of having:

The recognition of the different tissues which constitute the body (skin, muscles and bones) and their functions (protection, movement and structure).

The observation and analysis of individual bodily characteristics: shape, volume and weight.

Experimentation and research of the several kinds of movements and orientation in space (paths, directions and planes). [...] Improvisation and creation of sequences of movements with other students.

The recognition and exploration of space in pairs or other kinds of group formations.

The integration and communication with other by the means of gestures and movements (BRASIL, 1997a, p. 51). [authors translation]

Regarding competencies, the Portuguese Physical Education area document states:

In the situations of exploring group movement, with proper background music to the chosen theme: 4.1 - Matches mentioned abilities in 2, following group evolution in broken, arched, straight and mixed lines (simple and multiple).

- Adjusts their action to accomplish alterations or formation changes, suggested by the music dynamics and tempo, evolving in the whole area (PORTUGAL, 2001b, p. 72). [authors translation]

Pointing still as content of the Dance Portuguese Experimental Document for the 3rd cycle: It is from the curriculum framework (body-space, energy-relationship) that we can draw practical teaching guidelines for the $3^{\text {rd }}$ cycle.

The four elements will be approached respectively and repeatedly in the $7^{\text {th }}, 8^{\text {th }}$ and $9^{\text {th }}$ years, in a learning process of sedimentation and relationship games progressively more elaborate and complex.

Every time there is dance, the BODY moves in SPACE, in an ENERGY time and in a play of multiple relationships (PORTUGAL, [2004], p. 3) [authors translation].

Experimentation and exploration of principles of dance (body, space, energy, group relationships), as much as, objective and competences related to creation and individuality reveal the subjective indicators organized in dance field since Laban's ten themes approach proposed at Modern Educational Dance (1988) and deeply amplified by Preston-Dunlop (1986). These indicators are marked and moderated found in the Brazilian and Portuguese documents.

Absent and brief references were quoted mainly for interactionist indicators in both countries, even though they were larger in the Portuguese documents. Objectives, competences and content were the categories which the absence of interactionist indicators were mostly found. Brief references for interactionist indicators were more present on methodologies and forms of assessment. In the other hand, it was noted that objective indicators were quoted with absent and brief references in some of the Brazilian documents. 
General observation of the whole chart indicates: the predominance of objective indicators in Physical Education for both countries; the appearance of interactionist indicators mainly in the Brazilian documents; existence of objective and subjective indicators in the documents of both countries in all categories.

In a more detailed analysis of the proposals according to country and subject area we identify that:

1. In Brazil, the documents indicate the development of an objective proposal (scientific) in the cycles of the Fundamental Education (1997b; 1998b), taking a more interactionist position for Secondary Education (2006). However, the proposals for dance education in the guidelines documents for Physical Education show themselves to be insufficiently specific, from the dance point of view, as a field of knowledge and intervention as they discuss the contents of Physical Education (sport, games, fights, dances, gymnastics) in a more generalized manner, differently from the Art programs which develop dance specifically as language.

In this sense, Brasileiro (2009) by analyzing the proposals of training teachers of Physical Education and Art identifies that Physical Education recognizes the dance as a classic knowledge or area identifier, seeking to overcome its limitations in dealing with knowledge, especially at school, and along the teacher training process. However, this dimension of a more generalized form is still present.

2. In Portugal, dance as a curricular component of Physical Education presents a tendency of progression in the direction from subjective to objective (traditional) prioritizing the acquisition of abilities and techniques of forms of dance from the $3^{\text {rd }}$ cycle (social dances, traditional Portuguese dances, aerobics), even if as alternative activities.

3. In Brazil, dance in Art Education presents a growing tendency toward the construction and materialization of the interactionist discourse, if we analyze the year of production of the documents (1998 a 2006) and the levels of education (Fundamental to Secondary), being better structured in the Secondary Education, in the analysis of Art in contemporary societies in incorporating the view of cultural pluriculturalism. However, we understand that interactionism for dance is better realized as content, methodology and assessment in Fundamental Education from $5^{\text {th }}$ to $8^{\text {th }}$ years.

This interactionist perspective which was identified in the Art Brazilian proposals, with strong emphasis in contextualization and in a critical appropriation of contemporary art and society, seems to get organized from a North and South American referential, previously identified (MARQUES, 1999, 2003, 2012; SHAPIRO, 1998; STINSON, 1995, 1998a, 1998b, 2005; TAYLOR, 1994). This approach is shared by these women, researchers and teachers, from the United States of America and Brazil, who have been announcing the politics content of the objective (ballet) and subjective (creative dance) perspectives of dance education. Marques (1999), in an analogy of Lyotard's post-modernism analysis, called it as the metanarratives of dance education. Both perspectives in a modern or post-modern critical way of thinking objectify students, learners and citizens as idealized, mainly, fragile and happy female bodies.

4. In Portugal, the proposal of dance as an artistic discipline is restricted to the $3^{\text {rd }}$ cycle and is characterized by the balance between objective (traditional and scientific) and subjective with a slight tendency towards subjective, taking into consideration its predominance in the $7^{\text {th }}$ and $8^{\text {th }}$ years and the way the contents of the principles of dance are dealt with priority. 
The subjective attitude which is predominant in both countries shows a strong influence of the studies of Laban $(1978,1988)$, an author who was translated into Portuguese, in Brazil, at the end of the 1970's, despite never being translated in Portugal. This author, who is a world reference in the field of dance, has great influence is Dance Higher Education and Physical Education Colleges all over the world.

The objective perspectives (traditional and scientific) shown in the Portuguese proposal demonstrate the permanence of more traditional systems of dance education, as well as influence, in Portugal, of the scientific tendency, in a direct contamination of systematized discussions, above all, in the United Kingdom.

Monteiro (2007) synthesized Portuguese dance education historical route demonstrating how it shifts from French school, a body expression approach, which could be understood as a subjective perspective to Anglo-Saxon proposal, based on Laban's references and the British midway model for dance as an art form (SMITH-AUTARD, 1994), considered an objective perspective in our theoretical model (GEHRES, 2008).

\section{CONCLUSIONS}

This study aimed establishing an analysis of the fundamental principles of dance education (GEHRES, 2008) in national programs in Brazil and Portugal, examining the epistemic-methodological fundamentals of the curriculum guidelines for dance education in Brazil and Portugal.

The analysis of the guideline documents of the two countries showed a predominance of subjective proposals in both nations. However, it has been noted that Portugal and Brazil diverge in regards to the privilege to an objective approach in Portugal and interactionism in Brazil.

In order to continue this research and in the sequence of new investigation that we intend to conduct, it would be relevant to confront this analysis with the two other levels of existence in the curriculum, which are: operational curriculum (teachers) and the curriculum experienced by the students.

\section{REFERENCES}

ADSHEAD, Janet (Org.). Dance analysis: theory and practice. London: Dance Books, 1988.

BARDIN, Laurence. Análise de conteúdo. 6. ed. Lisboa: Edições 70, 2011.

BRASILEIRO, Lívia Tenorio. Dança e Educação Física: (in)tensas relações. 2009. 473f. Tese (Doutorado em Educação) - Universidade Estadual de Campinas, Campinas, 2009.

BRASILEIRO, Lívia Tenorio. O conhecimento no currículo escolar: o conteúdo dança em aulas de Educação Física na perspectiva crítica. 2001. 196f. Dissertação (Mestrado em Educação) - Universidade Federal de Pernambuco, Recife, 2001.

BRASIL. Ministério da Educação. Orientações curriculares para o ensino médio. Brasília, DF, 2006. 
BRASIL. Ministério da Educação. Parâmetros Curriculares Nacionais para o ensino médio. Brasília, DF, 2002.

BRASIL. Ministério da Educação. Parâmetros Curriculares Nacionais para o Ensino Fundamental - 5 a $8^{\mathbf{a}}$ séries - Arte. Brasília, DF, 1998a.

BRASIL. Ministério da Educação. Parâmetros Curriculares Nacionais para o Ensino Fundamental - 5a a $8^{\mathrm{a}}$ séries - Educação Física. Brasília, DF, 1998b.

BRASIL. Ministério da Educação. Parâmetros Curriculares Nacionais para o Ensino Fundamental -1a a 4⿳亠丷a séries - Arte. Brasília, DF, 1997a.

BRASIL. Ministério da Educação. Parâmetros Curriculares Nacionais para o Ensino Fundamental - 1aa a 4⿳亠丷a séries - Educação Física. Brasília, DF, 1997b.

CBCE. Educação física escolar frente à LDB e aos PCNs: profissionais analisam renovações, modismos e interesses. ljuí: Sedigraf, 1997.

DOMENICl, Eloisa. O encontro entre dança e educação somática como uma interface de questionamento epistemológico sobre as teorias do corpo. Pro-Posições, v. 21, n. 2, p. 69-85, 2010.

GEHRES, Adriana de Faria. Corpo-dança-educação na contemporaneidade ou da construção de corpos fractais. Lisboa: Instituto Piaget, 2008.

GENTILI, Pablo; SILVA, Tomaz Tadeu. Escola S.A.: quem ganha e quem perde no mercado educacional do neoliberalismo. Brasília: CNTE, 1996.

GREINER, Christine. 0 corpo: pistas para estudos indisciplinares. São Paulo: Annablume. 2008.

KELLY, Albert Victor. Knowledge and curriculum planning. London: Harper and Row, 1986.

LABAN, Rudolf. Dança educativa moderna. São Paulo. Ícone, 1988.

LABAN, Rudolf. Domínio do movimento. São Paulo: Summus, 1978.

MARQUES, Isabel. Dançando na escola. São Paulo: Cortez, 2003.

MARQUES, Isabel. Linguagem da dança: arte e ensino. São Paulo: Digitexto, 2010.

MARQUES, Isabel. O ensino de dança hoje: textos e contextos. São Paulo: Cortez, 1999.

MONTEIRO, Elisabete. Experiências criativas do movimento: infinita curiosidade. In: MOURA, M.; MONTEIRO, E. (Ed.). Dança em contextos educativos. Lisboa: FMH, 2007. p. 179-191.

PORTUGAL. Ministério da Educação. Organização Curricular e Programas - Ensino Básico

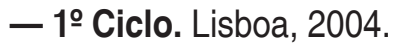

PORTUGAL. Ministério da Educação. Currículo Nacional do Ensino Básico: Competências essenciais. Lisboa, 2001a. Disponível em: <http://www.cfaematosinhos.eu/NPPEB 01 CN.pdf>. Acesso em: 28 mar. 2017.

PORTUGAL. Ministério da Educação. Dança: Orientações curriculares - 3ㅜ ciclo - ensino básico: Documento Experimental. Lisboa, [2004]. Disponível em: <https://www.esec.pt/pagina/ cdi/ficheiros/docs/Danca.pdf>. Acesso em: 7 jan. 2011. 
PORTUGAL. Ministério da Educação. Programa de Educação Física: Ensino Básico - 3ำ ciclo. Lisboa, 2001b. Disponível em: <https://www.dge.mec.pt/sites/default/files/ficheiros/eb ef programa 3c.pdf>. Acesso em: 28 mar. 2017.

PORTUGAL. Ministério da Educação. Programa Educação Física: 10ำ, 11ำ e 12․․ Lisboa, 2001c.

PORTUGAL. Ministério da Educação. Programa Educação Física: Plano de organização do ensino-aprendizagem - Ensino Básico - 2 ciclo. 3. ed. Lisboa, 1998. v 2.

PRESTON-DUNLOP, Valerie. A handbook for dance in education. London: Longman. 1986.

PRESTON-DUNLOP, Valerie. Deep and surface learning in Dance. In: International

Conference of Dance and the Child International. London : Dance and the Child International, c1988-1989. p. 228-231.

SHAPIRO, Sherry. Toward transformative teachers: feminist perspectives in dance education. Impulse, v. 4, p. 37-47, 1998.

SMITH-AUTARD, Jacqueline. The Art of Dance in Education. London: A \& C Black, 1994.

STINSON, Susan. Reflexões sobre a dança e os meninos. Pró-posições, v. 9, n. 2, p. 55-61, 1998a.

STINSON, Susan. Seeking a feminist pedagogy for children's Dance. In: SHAPIRO, Sherry B. (Org.). Dance, power and difference: Critical and feminist perspectives on Dance education. Champaign: Human Kinetics, 1998b.

STINSON, Susan. The hidden curriculum of gender in Dance education. Journal of Dance Education, v. 5, n. 2, p. 51-57, 2005.

STINSON, Susan. Uma pedagogia feminista para a dança da criança. Pró-posições, v. 6, n. 3, p. 77-89, 1995.

TAYLOR, Sherry B. Dança em uma época de crise social: Em direção a uma visão transformadora de dança-educação. Revista Comunicações e Artes, v. 17, n. 28, p. 65-74, 1994.

THOMAS, Jerry; NELSON, Jack. Métodos de pesquisa em atividade física e saúde. 3. ed. São Paulo: Artmed, 2002.

VIEIRA, Fernando. As orientações educacionais dos professores de educação física e o currículo institucional. Lisboa: Instituto Piaget, 2007. 
